九州大学学術情報リポジトリ

Kyushu University Institutional Repository

Identification and Characterization of a New Species, Cladobotryum hypsigum, that Causes Cobweb Disease in Beech Mushroom (Hypsizygus marmoreus) in Korea

Back, Chang-Gi

College of Agriculture and Life Sciences, Kyungpook National University

Lee, Seung-Yeol

College of Agriculture and Life Sciences, Kyungpook National University

Asaf, Sajjad

College of Agriculture and Life Sciences, Kyungpook National University

Kang, In-Kyu

College of Agriculture and Life Sciences, Kyungpook National University

他

https://doi.org/10.5109/1526290

出版情報：九州大学大学院農学研究院紀要. 60 (1)，pp.7-12，2015-02-27. Faculty of Agriculture， Kyushu University

バージョン :

権利関係: 


\title{
Identification and Characterization of a New Species, Cladobotryum hypsigum, that Causes Cobweb Disease in Beech Mushroom (Hypsizygus marmoreus) in Korea
}

\author{
Chang-Gi BACK ${ }^{1}$, Seung-Yeol LEE ${ }^{1}$, Sajjad ASAF ${ }^{1}$, In-Kyu KANG ${ }^{1}$, \\ Hee-Young JUNG ${ }^{*}$ and Shoji OHGA* \\ Laboratory of Forest Resources Management, Division of Forest Environmental Sciences, \\ Department of Agro-environmental Sciences, Faculty of Agriculture, \\ Kyushu University, Sasaguri, Fukuoka 811-2415, Japan \\ (Received October 3, 2014 and accepted November 14, 2014)
}

\begin{abstract}
Symptoms similar to the cobweb disease were observed on beech mushrooms (Hypsizygus marmoreus) growing in Cheongdo-gun, Gyeongbuk Province, Korea, in May 2013. The causal agent was collected and cultured on potato dextrose agar media at different temperatures $\left(5-30^{\circ} \mathrm{C}\right)$. The growth of the isolated fungus, characterized by the production of numerous sclerotia and red pigments, was temperature dependent, with minimum growth at $5^{\circ} \mathrm{C}$ and maximum growth at $25^{\circ} \mathrm{C}$. A pathogenicity test revealed that the isolated fungus causes cobweb disease in the host mushroom H. marmoreus (white) as well as in three other mushrooms-H. marmoreus (brown), Flammulina velutipes, and Pleurotus eryngii-with massive mycelia and few conidia. Phylogenetic analysis of four genes (ITS, RPB1, RPB2, and TEF) showed that this isolate has a unique lineage and is distantly related to other species of Cladobotryum that cause the cobweb disease. The results showed that the isolated fungus is a new species, herein named Cladobotryum hypsigum, which causes cobweb disease in H. marmoreus in Korea.
\end{abstract}

Key words: Beech mushroom, Cladobotryum hypsigum, Cobweb disease, Mushroom disease

\section{INTRODUCTION}

Cobweb disease in mushrooms is characterized by the growth of coarse mycelia (Fletcher, et al., 1989). For decades, Hypomyces rosellus was the most commonly reported pathogen of cobweb disease (McKay et al., 1998; Bhatt and Singh, 2002; Potocnik et al., 2008); however, during the last decade, the anamorph of Hypomyces odoratus has been reported with increasing frequency as the agent responsible for this disease, which has led to significant economic losses in commercial cultivation of mushrooms, mainly Agaricus bisporus (McKay et al., 1999; Grogan and Gaze, 2000; Adie et al., 2006; Khan et al., 2008; Back et al., 2010, 2012; Gea et al., 2011, 2012). Reports have suggested that various Cladobotryum species such as Cladobotryum dendroides, C. mycophilum, C. varium, C. multiseptatum, and C. verticillatum cause diseases in several mushrooms (McKay et al., 1999; Adie et al., 2006).

The common symptoms of infection with Cladobotryum, the causal agent of cobweb disease, are the production of conidial masses and brown spots on mushroom caps (Back et al., 2010). Studies of the infection pattern have suggested that the cobweb pathogen grows after infecting the casing layer. The rapid growth is assisted by spore dispersal in growing-rooms, covering the casing soil and the mushrooms with white cottonlike mycelium that can turn pinkish over time. The landing spores on developing mushrooms causes spotting,

1 College of Agriculture and Life Sciences, Kyungpook National University, 80 Daehakro, Buk-gu, Daegu 702-701, Korea

* Corresponding author (E-mail: heeyoung@knu.ac.kr, ohga@ forest.kyushu-u.ac.jp) whereas fruit bodies overgrown by mycelia develop soft, wet rot. The reported infections have mainly been attributed to the aurofusarin-producing fungal species $H$. rosellus, H. odoratus, and C. multiseptatum (Tamm and Poldmaa, 2013). Other aurofusarin-producing Cladobotryum species such as C. asterophorum, C. protrusum, and C. paravirescens have been reported on agaric, decorticated wood, and aphyllophoralean basidiomycete fungi, respectively. Although these species have been isolated from different hosts and are differ from one another in conidia shape, size, and sclerotia-like aggregation, they all form the same pale, reddish pigments on potato dextrose agar (PDA) media due to aurofusarin (a secondary metabolite in Cladobotryum species) (De Hoog, 1978; Põldmaa, 2011).

Plant pathologists are continuously seeking ways to suppress diseases such as cobweb disease to prevent economic loss. Chemical fungicides such as benzimidazole are generally used against cobweb disease-causing fungi on mushroom farms. However, C. mycophilum and $C$. dendroides became resistant to benzimidazole fungicides in the United Kingdom and are difficult to control (Grogan, 2006).

Hypsizygus marmoreus (beech mushroom) is an asidiomycete fungus cultivated for food in Korea, Japan, and Taiwan (Lee et al., 2007). This mushroom is not only a delicious and nutritious food but also a source of hypsin, a ribosome-inactivating protein with documented medicinal qualities (Lam and $\mathrm{Ng}, 2001$ ). The natural compounds in H. marmoreus have antitumor (Ikekawa et al., 1992, 1995; Tsuchida et al., 1995), antifungal, and antiproliferative activities (Lam and Ng, 2001).

In 2010, Back et al. identified $C$. varium as a causal agent of cobweb disease in $H$. marmoreus on commer- 
cial mushroom farms in Cheongdo-gun in the Gyeongbuk Province of Korea. However, in 2013, cobweb disease with different symptoms was observed in $H$. marmoreus. The white mycelium-covered fruit bodies of affected mushrooms had fewer conidia and a more scattered infection pattern compared to those infected by $C$. varium (Back et al., 2012). Therefore, the purpose of this study was to isolate and identify the new causal agent of this disease using morphological and molecular characterization.

\section{MATERIALS AND METHODS}

\section{Isolation and growth of fungi}

The fungal samples were isolated in Cheongdo-gun, Gyeongbuk Province, Korea, in May 2013, from a diseased fruit body of $H$. marmoreus (white) with brown spots on the cap and few conidia, and it was covered with massive mycelium. The isolated fungi were cultured on PDA media in the dark at $25^{\circ} \mathrm{C}$ for 3 days. To confirm the morphological characteristics, we examined the shape, size, and color of 100 conidia and conidiophores of the isolated fungus using a microscope, Olympus BX-50 (Olympus, Tokyo, Japan). The fungus was then characterized using the descriptions of Gams and Hoozemans (1970) and Põldmaa (2011). The mycelial plugs (less than $5 \mathrm{~mm}$ in diameter) were placed in the center of PDA media plates ( $90 \mathrm{~mm}$ in diameter). The plates were incubated at temperatures of $5^{\circ} \mathrm{C}, 10^{\circ} \mathrm{C}, 15^{\circ} \mathrm{C}, 20^{\circ} \mathrm{C}, 25^{\circ} \mathrm{C}$, and $30^{\circ} \mathrm{C}$ for $8 \mathrm{~d}$ to identify the optimum growth temperature. The growth rate of the isolate was observed after $8 \mathrm{~d}$, and the experiment was performed in triplicate.

\section{Pathogenicity tests}

Pathogenicity tests were performed at the first pinhead stage on four bottle-cultured mushrooms: $H$. marmoreus (white), H. marmoreus (brown), F. velutipes, and $P$. eryngii. The inocula were prepared using 10-day-old cultures on PDA media and adjusted to $1 \times$ $10^{2}$ conidia/mL. The spore suspension was sprayed on H. marmoreus (white). The inoculated mushrooms were covered with plastic bags to maintain humidity higher than $80 \%$ for $24 \mathrm{~h}$ and then incubated at $20^{\circ} \mathrm{C}$. The pathogenicity of the isolated fungus was studied by using it to inoculate three additional mushrooms- $H$. marmoreus (brown), F. velutipes, and P. eryngii-following the procedure used for the initial inoculation.

\section{DNA extraction and polymerase chain reaction (PCR) amplification}

Total genomic DNA was extracted from the isolated fungus using lysis buffer according to a procedure described by Liu et al. (2000). The resultant total genomic DNA was used to amplify four protein-coding genes for internal transcribed spacer (ITS) region, RNA polymerase II subunit 1 (RPB1), RNA polymerase II subunit 2 (RPB2), and translation elongation factor ( $T E F$ ) (exon 6 was amplified). These genes were amplified using the following primer pairs: gene for ITS: ITS $1 F$ (5'-CTT GGT CAT TTA GAG GAA GTA A-3')/ITS4 (5'-
TCC TCC GCT TAT TGA TAT GC-3') (White et al., 1990); RPB1: cRPB1Af (5'-CAY CCW GGY TTY ATC AAG AA-3')/cRPB1Cr (5'-CCN GCD ATN TCR TTR TCC ATR TA-3') (Chaverri et al., 2008); RPB2: RPB2-5f (5'-GAY GAY MGW GAT CAY TTY GG-3')/7cR (5'-CCC ATR GCT TGY TTR CCC AT-3') (Liu et al., 1999); TEF: EF1-983F (5'-GCY CCY GGH CAY CGT GAY TTY AT-3') (Carbone and Kohn, 1999), EF1-2218R (5'-ATG ACA CCR ACR GCR ACR GTY TG-3') (Rehner, 2001).

PCR amplification was performed in $20 \mu \mathrm{L}$ of the reaction mixture containing $20 \mathrm{ng}$ of fungal genomic DNA, 5 U of Taq polymerase (BIOFACT, Daejeon, Korea), $2 \mu \mathrm{L}$ of $10 \mathrm{X}$ reaction buffer (100 mM Tris-HCl, $400 \mathrm{mM}$ $\mathrm{KCl}, 15 \mathrm{mM} \mathrm{MgCl} 2, \mathrm{pH} 9.0$ ), $10 \mathrm{mM}$ dNTP mixture, and 10 pmol of each primer using an Applied Biosystems 2720 thermal cycler (Applied Biosystems, Foster City, $\mathrm{CA})$. The PCR conditions were $94^{\circ} \mathrm{C}$ for $3 \mathrm{~min} ; 35$ cycles of $30 \mathrm{~s}$ at $94^{\circ} \mathrm{C}, 30 \mathrm{~s}$ at $55^{\circ} \mathrm{C}$ for ITS and at $57^{\circ} \mathrm{C}$ for $R P B 1, R P B 2$, and $T E F$, and 1 min at $72^{\circ} \mathrm{C}$; and a final extension at $72^{\circ} \mathrm{C}$ for $7 \mathrm{~min}$. The PCR products were electrophoresed using 1\% agarose gel and visualized in an ultraviolet illuminator. Then, the amplified DNA fragments were purified using a HiGeneTM Gel \& PCR Purification system (BIOFACT).

\section{Sequencing and phylogenetic analysis}

The purified DNA fragments were subjected to direct sequencing (BIOFACT). The sequences of the four genes were edited and aligned using DNASTAR (DNASTAR Inc., Madison, Wis.). The sequences were combined, and phylogenetic trees were constructed using the neighborjoining method in CLUSTAL W (Thompson et al., 1994). The phylogenetic trees for the four combined sequences were constructed from the data using the TreeView program (Win32, ver. 1.6.1). Bootstrap analysis with 1,000 replications was performed to determine support for various clades.

\section{RESULTS AND DISCUSSION}

\section{Morphological characteristics of the isolated fungi}

The natural symptoms of cobweb disease, including the growth of mycelium covering the affected mushrooms, production of few conidia, and brown spots on the mushroom caps, were observed on $H$. marmoreus in Cheongdo-gun in the Gyeongbuk Province in Korea in May 2013. In the early stages, white mycelia covered the fruit bodies of young mushrooms, whereas the infected fruit bodies rotted and masses of mycelia with few conidia covered them entirely in later stages (Fig. 1A-C). These symptoms differed from those previously reported for cobweb disease in H. marmoreus caused by $C$. varium (Back et al., 2012).

According to our results, the isolate formed white mycelia on PDA media during the early stages at $22^{\circ} \mathrm{C}$. This mycelium turned yellow after 8 days and then pinkish-red after 15 days (Fig. 1D and E). However, numerous sclerotia were observed after 20 days (Fig. 1E). The conidiophores were branched with two-celled conidia that are 15.9-21.8 $\mu \mathrm{m}$ long, 6.3-9.2 $\mu \mathrm{m}$ thick, and ovoid, 


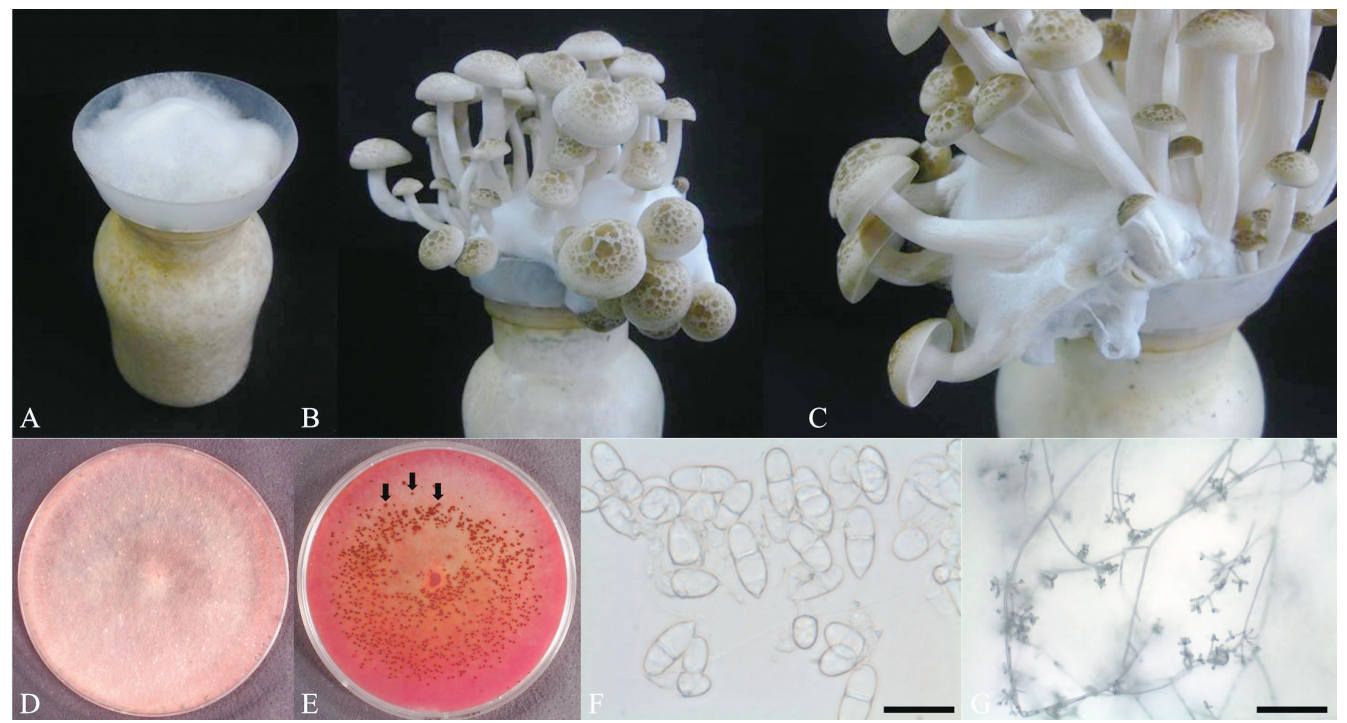

Fig. 1. Morphological characteristics of the isolated fungus. A: Symptoms of cobweb disease on host, B: Fruit body formation on host. C: Enlarged image of B. D: Colony of isolated fungus on potato dextrose agar (PDA) after 20 days at $22^{\circ} \mathrm{C}$ (front view). E: Development of sclerotia-like bodies (arrows) from the center of the colony (back view). F, Light microscope micrograph showing conidial morphology. G: Conidiophore-bearing conidia. Scale bars: $\mathrm{F}=20 \mu \mathrm{m}, \mathrm{G}=100 \mu \mathrm{m}$.

Table 1. Comparison of the morphological characteristics of the isolated fungi and other Cladobotryum species on potato dextrose agar media

\begin{tabular}{|c|c|c|c|c|c|}
\hline & This study & C. varium & C. asterophorum & C. paravirescens & C. protrusum \\
\hline Size (conidia) & $15.9-21.8 \times 6.3-9.2$ & $8.6-15.8 \times 6.4-8.6$ & $14-23 \times 5.5-7.5$ & $18.0-27.5 \times 6.5-10.0$ & $16.0-27 \times 5.5-9.0$ \\
\hline Shape (conidia) & Two-celled & Two-celled & Two-celled & - & - \\
\hline Shape (conidiospore) & Simple branch & Simple branch & Simple branch & Verticillate & $\begin{array}{l}\text { Verticillate, } 2-4 \\
\text { branches }\end{array}$ \\
\hline Pigment (on plate) & Yellow to red & Cream & Pale crimson & Yellow to crimson & $\begin{array}{l}\text { Yellow to brick } \\
\text { brown or purple }\end{array}$ \\
\hline Form of sclerotium & Formed sclerotium & Absent & Not reported & $\begin{array}{l}\text { Sclerotia-like } \\
\text { aggregation }\end{array}$ & $\begin{array}{l}\text { Sclerotia-like } \\
\text { aggregation }\end{array}$ \\
\hline Additional characteristics & $\begin{array}{l}\text { Rarely produces } \\
\text { spores }\end{array}$ & $\begin{array}{l}\text { Produces many } \\
\text { spores }\end{array}$ & $\begin{array}{l}\text { Produces profuse } \\
\text { spores }\end{array}$ & Not reported & Not reported \\
\hline Reference & & Back et al., 2012 & De Hoog, 1978 & Põldmaa, 2011 & Põldmaa, 2011 \\
\hline
\end{tabular}

with large truncate basal hila (Fig. 1F). These morphological characteristics differ from those of a previously reported causal agent of cobweb disease in $H$. marmoreus (Back et al., 2012). The pigment color of the isolated fungi was similar to that of three Cladobotryum species (C. asterophorum, C. paravirescens, and $C$. protrusum; Table 1). However, these species have been isolated from different hosts, not from edible mushrooms. The conidia size of the fungi isolated in the present study $(15.9-21.8 \times 6.3-9.2 \mu \mathrm{m})$ also differs from those of previously reported Cladobotryum species (Table 1). Given these differences, we presumed that the new isolate is a new and important Cladobotryum species causing cobweb disease in edible mushrooms. However, only morphological characteristics were insufficient for species identification, and we therefore needed to study additional parameters to confirm the identity of this new isolate.

\section{Effect of temperature on mycelial growth}

The effect of temperature on fungal growth was investigated at temperatures ranging from $5^{\circ} \mathrm{C}$ to $30^{\circ} \mathrm{C}$ after 15 days of incubation. The criterion for optimum growth was colony diameter, which was maximum (90$\mathrm{mm}$ diameter) at $25^{\circ} \mathrm{C}$ and minimum (25-mm diameter) at $5^{\circ} \mathrm{C}$ (Fig. 2). The color of the mycelia also changed to pink and, later, turned reddish after 15 days (Fig. 2). Similar red pigments have been reported in C. mycophilum from P. eryngii, A. bisporus, C. asterophorum, C. paravirescens, and C. protrusum, grown on PDA media and are due to aurofusarin, a secondary metabolite of the Cladobotryum species (Põldmaa, 2011).

\section{Pathogenicity tests}

The results of the pathogenicity tests were verified by inoculating healthy $H$. marmoreus (white) with the isolated fungus. The same cobweb-like disease symptoms 


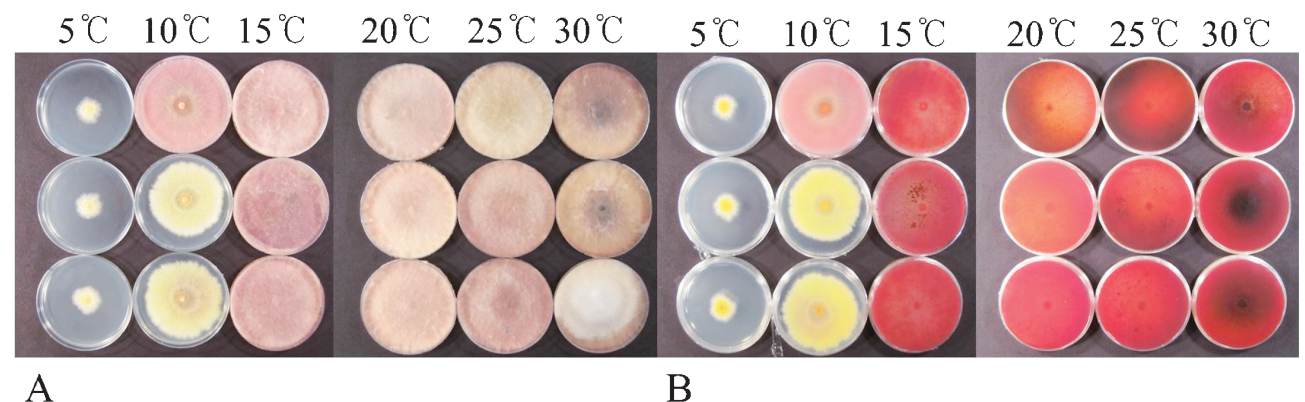

A

B

Fig. 2. Effect of temperatures between $5^{\circ} \mathrm{C}$ and $30^{\circ} \mathrm{C}$ on mycelial growth of the isolated fungus on PDA 15 days after incubation (A: Front view, B: Back view of plate).

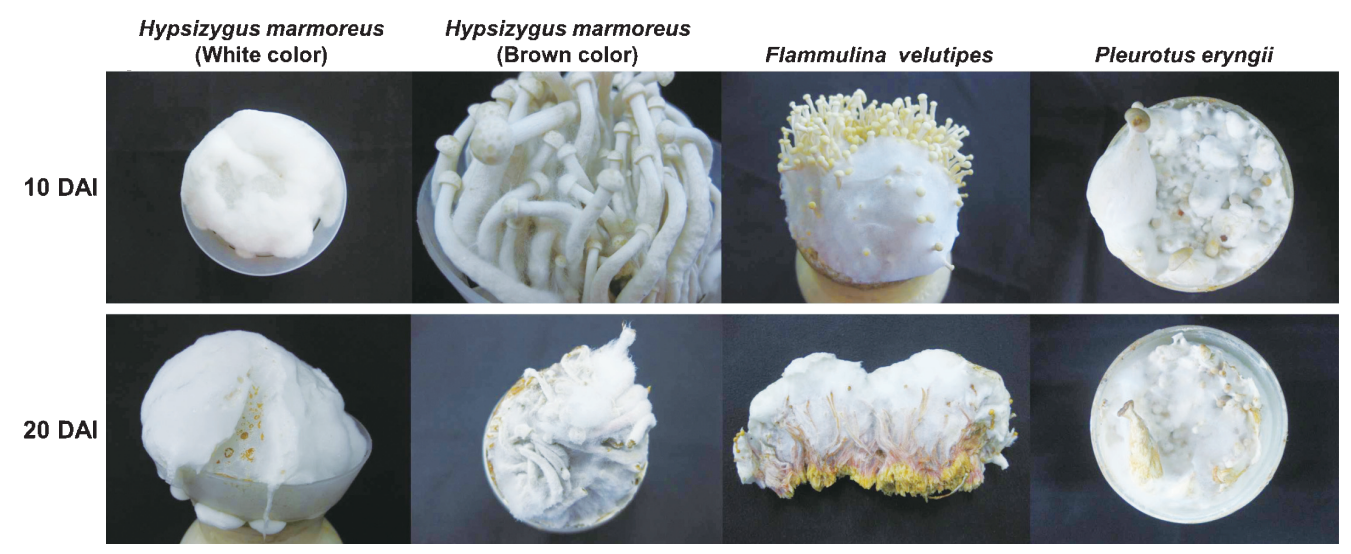

Fig. 3. Pathogenicity tests of the isolated fungus on four mushrooms at $20^{\circ} \mathrm{C}$. DAI: days after inoculation.

developed on the inoculated mushrooms within 3 days after inoculation (DAI; Fig. 3). Rotted fruit bodies and few spores were observed 10 days later (Fig. 3). The development of the disease on the inoculated mushrooms resembled that on naturally infected mushrooms. The pathogenicity of the isolated fungus was also tested in $H$. marmoreus (brown), F. velutipes, and $P$. eryngii using the procedure followed for the initial inoculation. At 3 DAI, the symptoms of the cobweb-like disease were observed in all mushrooms, whereas rotted fruit bodies and mycelia were observed at 10 DAI (Fig. 3). All inoculated mushrooms were entirely rotted at $20 \mathrm{DAI}$, and reddish fruit bodies, massive mycelia, and few conidiospores were observed (Fig. 3). These symptoms are similar to those of cobweb disease of mushroom farms. However, the characteristics of this disease differ from the previous description of cobweb disease in $H$. marmoreus caused by $C$. varium in the presence of few conidia and reddish rotted fruit bodies; in the previously reported cobweb disease, numerous conidiospores are produced (Back et al., 2012).

\section{Phylogenetic analysis}

Molecular characterization of the isolated fungi was performed based on gene encoding the ITS region, $R P B 1$, $R P B 2$, and TEF. Direct sequencing of the PCR products of the amplified gene for the ITS region, $R P B 1, R P B 2$, and $T E F$ resulted in sequences of $622 \mathrm{bp}, 728 \mathrm{bp}, 1,135$ $\mathrm{bp}$, and $970 \mathrm{bp}$, respectively (data not shown). All of the sequences of the identified isolates for each gene were $100 \%$ identical to each other. According to our results, these isolate differs from previously reported isolates of Cladobotryum sp. in Korea that cause cobweb disease in mushrooms such as A. bisporus, P. eryngii, F. velutipes, and H. marmoreus (Kim et al., 1998, 1999; Back et al., 2010, 2012). The sequences obtained for the fungus were deposited in the DNA Data Bank of Japan/ GenBank database under the accession numbers AB969671 for the ITS region, AB969673, AB969674 for the $R P B 1$ and $R P B 2$, respectively, and $\mathrm{AB} 969675$ for the $T E F$. The phylogenetic analysis of the isolated fungus was carried out based on the combined sequences (ITS region, $R P B 1, R P B 2$, and $T E F$ ), and the results showed that the isolated fungus has a new lineage that differs from those of the previously reported Cladobotryum species (Fig. 4).

In the present study, a new species of Cladobotryum was isolated from $H$. marmoreus in Cheongdo-gun, Gyeongbuk Province, Korea. Its morphological characteristics of sclerotia formation, pigmentation, and conidia formation (shape and size) were distinct from those of previously reported $C$. varium species that cause cobweb disease in H. marmoreus (Back et al., 2012). The morphological delimitation of the isolated fungi as a unique species was further supported by the phylogenetic analysis of four genes (gene for ITS, $R P B 1, R P B 2$, 


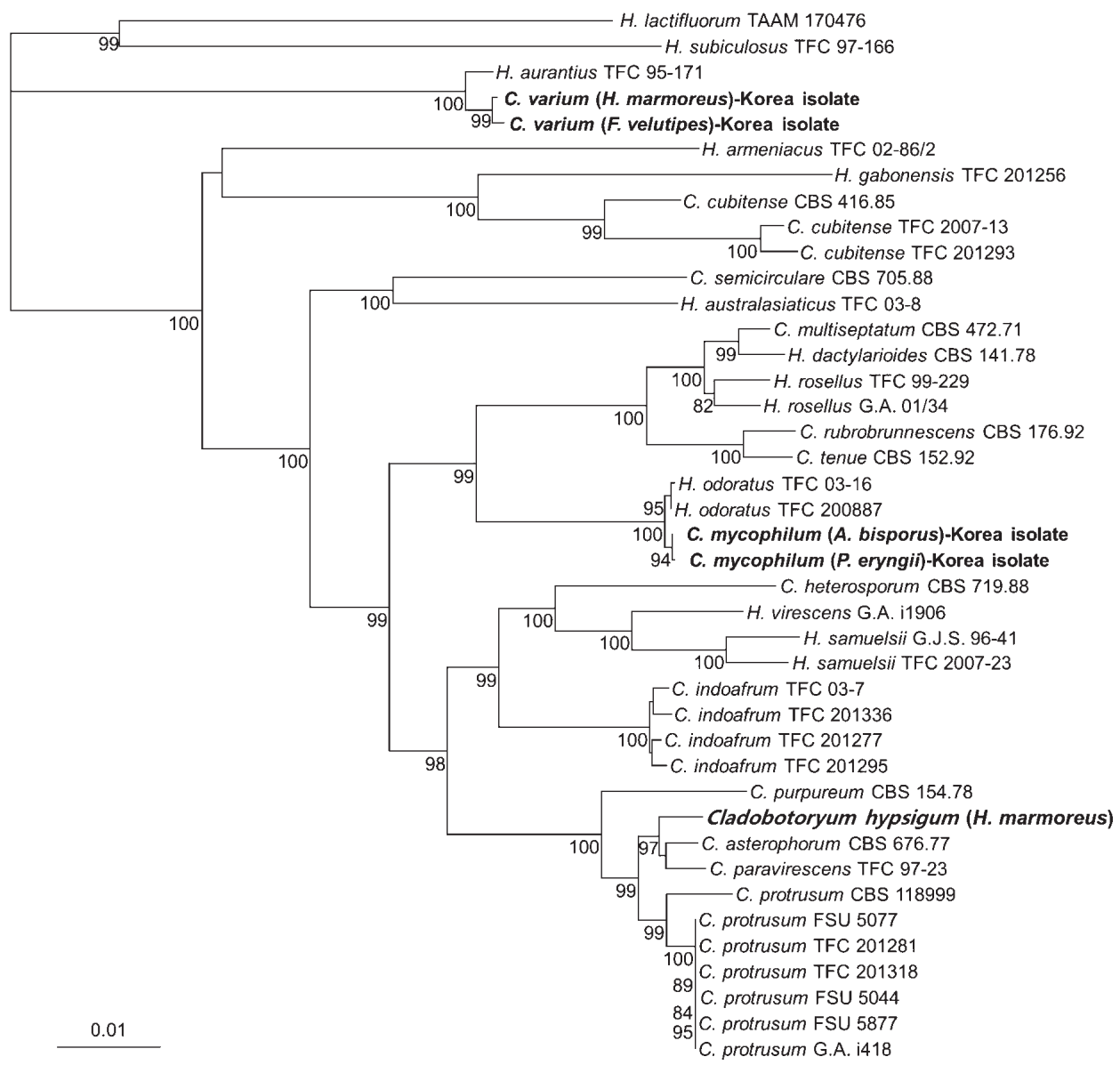

Fig. 4. Phylogenetic tree constructed using the neighbor-joining method based on a comparison of four sequences (ITS region, RPB1, RPB2, and TEF) of Cladobotryum spp. with those of other Cladobotryum species from GenBank. Hypomyces lactifluorum and Hypomyces subiculosus formed the out group. The Cladobotryum species observed in this study are shown in bold font. Numbers on the branches are the confidence values obtained for 100 replicates (only values above $80 \%$ are shown). The bar represents a phylogenetic distance of $1 \%$.

and $T E F$ ). The results showed that the isolated fungi belong to the same clade as $C$. protrusum and C. paravirescens; however, it forms a new lineage that is distant from other Cladobotryum species. Furthermore, pathogenicity tests revealed that the isolated pathogen also causes cobweb disease in $F$. velutipes and $P$. eryngii; however, natural infection has not yet been reported in these mushrooms.

Although this newly identified pathogen has been isolated less frequently than C. varium in Cheongdogun, Gyeongbuk Province in Korea, its potential threat to $H$. marmoreus and other mushrooms in Korea remains. The disease caused by this pathogen in $H$. marmoreus is of particular importance because it has been cultivated occasionally on approximately 10 mushroom farms in Korea. The results of the phylogenetic analysis showed that the isolated pathogen forms a new lineage; however, it belongs to same clade as C. protrusum and C. paravirescens, which have been isolated in decorticated wood and aphyllophoralean basidiomycetes, respectively. Moreover, previous reports have suggested that H. marmoreus on mushroom farms is cultivated on substrates consisting of pine sawdust or wood chips (Lee et al., 2011). Therefore, the similar pigment color and phylogenetic analysis of this isolated pathogen suggest that it may exist in the wood chips or sawdust used in mushroom media.

The presence of our isolated pathogen on $H$. marmoreus suggests that it may be adaptive to the environmental conditions in $H$. marmoreus farms, and that it was likely transmitted through wood chips. Furthermore, the cultivation period of $H$. marmoreus, which is three times longer than that of other mushrooms, may help this pathogen grow and cause infection. However, further research is needed to identify the infection pattern of this fungus. On the basis of previously published literature and the results of the present study, we identified this isolated pathogen as a new C. hypsigum species that causes cobweb disease in H. marmoreus in Korea.

\section{REFERENCES}

Adie, B., H. Grogan, S. Archer and P. Mills 2006 Temporal and spatial dispersal of Cladobotryum conidia in the controlled environment of a mushroom growing room. Appl. Environ. Microbiol., 72: 7212-7217

Back, C. G., C. Y. Lee, G. S. Seo and H. Y. Jung 
Characterization of species of Cladobotryum which cause cobweb disease in edible mushrooms grown in Korea. Mycobiology, 40: $189-194$

Back, C. G., C. Y. Lee, G. S. Seo, H. Y. Jung and S. Oga 2012 First occurrence of cobweb disease on Hypsizigus marmoreus caused by Cladobotryum varium in Korea. J. Fac. Agr. Kyushu Univ., 57: 373-377

Back, C. G., Y. H. Kim, W. S. Jo, H. Chung and H. Y. Jung 2010 Cobweb disease on Agaricus bisporus caused by Cladobotryum mycophilum in Korea. J. Gen. Plant Pathol., 76: 232-235

Bhatt, N. and R. P. Singh 2002 Chemical control of mycoparasites of button mushroom. Indian. J . Mycol. Plant Pathol., 32: $38-45$

Cabone, I. and L. M. Kohn 1999 A method for designing primer sets for speciation studies in filamentous ascomycetes. Mycologia, 91: 553-556

Chaverri, P., M. Liu and K. T. Hodge 2008 Neotropical Hypocrella (anamorph Aschersonia)., Moelleriella, and Samuelsia. Studies in Mycology, 60: 1-68

De Hoog, G. S. 1978 Notes on some fungicolous hyphomycetes and their relatives. Persoonia., 10: 33-81

Fletcher, J. T., P. F. White and R. H Gaze 1989 Mushrooms: pest and disease control. Andover, Hants, England: Intercept. pp. $58-63$

Gams, W. and A. C. M. Hoozemans 1970 CladobotryumKonidienformen von Hypomyces-Arten. Persoonia., 6: 95-110

Gea, F. J., M. J. Navarro and L. M. Suz 2011 First report of Cladobotryum mycophilum causing cobweb on cultivated king oyster mushroom in Spain. Plant Dis., 95: 1030

Grogan, H. M. 2006 Fungicide control of mushroom cobweb disease caused by Cladobotryum strains with different benzimidazole resistance profiles. Pest. Manag. Sci., 62: 153-161

Grogan, H. M. and R. H. Gaze 2000 Fungicide resistance among Cladobotryum spp. - causal agent of cobweb dis ᄀease of the edible mushroom Agaricus bisporus. Mycol. Res., 104: 357364

Ikekawa, T. 1995 Bunashimeji, Hypsizigus marmoreus: antitumor activity of extracts and polysaccharides. Food Rev. Int., 11: $207-209$

Ikekawa, T., H. Saitoh, W. Feng, H. Zhang, L. Li and T. Matsuzawa 1992 Antitumor activity of Hypsizigus marmoreus. I. Antitumor activity of extracts and polysaccharides. Chem. Pharm. Bull., 40: 1954-1957

Khan, I., F. Shah, S. Bulman and I. Scott 2008 Molecular diagnostic tools for improved mushroom production. In: Abstracts of the XVII International Congress on the Science and Cultivation of Edible and Medicinal Fungi. Cape Town.

Kim, T. S., H. U. Lee., K. W. Song and W. K. Shin 1998 King oyster mushroom (Pleurotus eryngii) white mold disease caused by Cladobotryum varium. KSM News Letter (The Korean Society of Mycology), 11: 46

Kim, H. K., S. J. Seok, G. P. Kim, B. J. Moon and T. Terashita 1999 Occurrence of disease caused by Cladobotryum varium on
Flammulina velutipes in Korea. Kor. J. Mycol., 27: 415-419 Lam, S. K. and T. B. Ng 2001 Hypsin, a novel thermostable ribosome-inactivating protein with antifungal and antiproliferative activities from fruiting bodies of the edible mushroom Hypsizigus marmoreus. Biochem. Biophys. Res. Commun., 285: 1071-1075

Lee, C. Y., J. E. Park, J. Lee, J. K. Kim and H. S. Ro 2011 Development of new strains and related SCAR markers for an edible mushroom, Hypsizygus marmoreus. FEMS. Microbiol. Lett., 327: 54-59

Lee, Y. L., M. T. Yen and J. L. Mau 2007 Antioxidant properties of various extracts from Hypsizigus marmoreus. Food Chem. 104: $1-9$

Liu, D., S. Coloe, S. Baird, J. Pedersen 2000 Rapid mini-preparation of fungal DNA for PCR. J. Clin. Microbiol., 38: 471

Liu, Y. J., S. Whelen and B. D. Hall 1999 Phylogenetic relationships among ascomycetes, as inferred from RNA polymerase II phylogeny. Mol. Biol. Evol., 16: 1799-1808

McKay, G. J., D. Egan, E. Morris and A. E. Brown 1998 Identification of benzimidazole resistance in Cladobotryum dendroides using a PCR-based method. Mycol. Res., 102 671-676

McKay, G. J., D. Egan, E. Morris, C. Scott and A. E. Brown 1999 Genetic and morphological characterization of Cladobotryum species causing cobweb disease of mushrooms. Appl. Environ. Microbiol., 65: 606-610

Põldmaa, K. 2011 Tropical species of Cladobotryum and Hypomyces producing red pigments. Stud Mycol., 68: 1-34

Potocnik, I., J. Vukojevic, M. Stajic, B. Tanovic and B. Todorovic 2008 Fungicide sensitivity of selected Verticillium fungicola isolates from Agaricus bisporus farms. Arch. Biol. Sci. (Belgrade)., 60: 151-157

Rehner, S. A. 2001 Primers for elongation factor 1-alpha (EF1alpha). http://ocid.nacse.org/research/deephyphae/EF1primer. pdf

Tamm, H. and K. Põldmaa 2013 Diversity, host associations, and phylogeography of temperate aurofusarin-producing Hypomyces/Cladobotryum including causal agents of cobweb disease of cultivated mushrooms. Fungal Biol., 117: 348-367

Thompson, J. D., D. G. Higgins and T. J. Gibson 1994 CLUSTAL W: improving the sensitivity of progressive multiple sequence alignment through sequence weighting, position-specific gap penalties and weight matrix choice. Nucl. Acids. Res., 22 $4673-4680$

Tsuchida, K., Y. Aoyagi, S. Odani, T. Mita and M. Isemura 1995 Isolation of a novel collagen-binding protein from the mushroom, Hypsizigus marmoreus, which inhibits the Lewis lung carcinoma cell adhesion to type IV collagen. J. Biol. Chem., 270: $1481-1484$

White, T. J., T. Bruns, S. Lee and J. Taylor 1990 Amplification and direct sequencing of fungal ribosomal RNA genes for phylogenetics. PCR Protocols: A Guide to methods and applications, Academic Press, San Diego, CA, USA, 315-322 